Article

\title{
Comparison of Water Resources Policies between Brazil and Italy
}

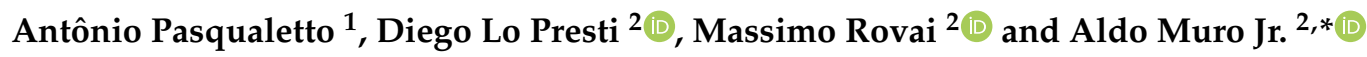 \\ 1 Engineering Department, The Pontifical Catholic University of Goiás and Federal Institute of Education, \\ Science and Technology of Goiás, Goiânia 74.175-120, Brazil; profpasqualetto@gmail.com \\ 2 Department of Civil and Industrial Engineering, University of Pisa, 56.122 Pisa, Italy; \\ d.lopresti@ing.unipi.it (D.L.P.); massimo.rovai@unipi.it (M.R.) \\ * Correspondence: aldo.muro@ing.unipi.it or murojr@gmail.com; Tel.: +55-62-99992-2424
}

Received: 17 September 2019; Accepted: 29 October 2019; Published: 27 November 2019

check for updates

\begin{abstract}
The growing need for water has pressured society and governments to focus more on preservation, planning and management of this natural resource, which is fundamental to ecosystems, especially to humans. Therefore, the goal of this study was to analyze the national policies of water resources in Brazil and Italy, searching for aspects that could promote improvement, aiming at the preservation of water sources, guaranteeing satisfactory quantity and quality. In 2019, studies were carried out by environmental agencies of both countries, listing the main disciplinary regulations. Results show that although both countries have different realities, they have similarities in managerial aspects of water resources, with legislation addressing qualitative and quantitative aspects of water, with guiding principles, instruments and actions aimed at the defense of this natural resource.
\end{abstract}

Keywords: water management; planning; water resources; water sustainability policies; water laws

\section{Introduction}

Air Water resource is a relevant subject of the environmental crisis, and one of the main challenges faced by humanity. The uneven distribution on the Earth's surface; factors related to waste and mismanagement; the increasingly alarming context of pollution and contamination of water resources; and population growth, especially in developing countries, is a crucial concern of public officials and society.

De Macedo (2007) in his book, "Waters and Waters" describes the importance of this natural resource. The UN is warning that by 2025, almost two-thirds of the world's population will live in metropolitan areas, causing serious supply problems. According to UN (Itália 1947), the expected human population will be around 8.6 billion by 2030, 9.8 billion by 2050 and 11.2 billion by 2100 .

In this sense, there will be a great need for proper management of water resources, allowing different uses, ensuring desirable quantity and quality. Many actions could be taken, such as re-evaluating the form of development, the pattern of consumption, the unequal distribution of wealth and the employee technological standard.

The principle of sustainability implies the use of renewable resources at rates equal to or less than its regeneration. Water sustainability implies maintaining a dynamic balance between supply and demand for water.

This fact justifies the need for studies from the sustainability perspective in the use of these natural resources, taking advantage of the resulting creation of the legal framework that supports the management of water resources.

This legislation constitutes a fundamental instrument in establishing specific policies for water resources and how to manage planning and management. 
In this sense, we compared water resources policies between Brazil and Italy, enabling improvement within the planning and management mechanisms of these countries, and by meeting the ecosystem support capacity.

\section{Materials and Methods}

In both countries, environmental agencies were the main sources of consultation in 2019. In Brazil, the main sources were the National Water Agency (ANA) and the National Water Resources System, while in Italy the information was obtained through consultations from the European Environmental Agency-EEA, the Institute of Environmental Protection and Research-ISPRA, the National System of Environmental Protection, and the data expressed in tables and figures that illustrate the results obtained.

\section{Methodology}

The research was conducted in 2019, and the study was characterized as exploratory qualitative and quantitative.

Qualitative when focused on the normative documentary analysis of content and quantitative with data from administrative and hydrographic areas.

Initially, it addresses models of water governance in the world and the origin of the current systems used in the countries being researched.

Data was collected in Brazil and Italy, and in both countries, environmental agencies were the primary sources of consultation.

In Brazil, the primary sources were the National Water Agency-ANA, and the National Water Resources System. While in Italy, the databases of the European Environmental Agency-EEA, the Higher Institute for Environmental Protection and Research-ISPRA, and the National Environmental Protection System were consulted.

Among the qualitative variables considered were the guiding principles of current legislation, critical milestones in history, and the planning and management instruments operationalized.

Finally, positive and negative aspects of the implementation of water resource policies in Brazil and Italy expressed in actions and perspectives.

For the quantitative variables, a summary of the administrative and hydrographic areas of Brazil and Italy was presented, highlighting:

(a) Geographic Region;

(b) Administrative Region;

(c) State;

(d) Province;

(e) Municipality or Commune; Region or Hydrographic District.

The results are expressed in tables and figures that illustrate the results obtained.

\section{Results and Discussion}

\subsection{Principles of Water Governance}

The history of planning and management of water resources begins with hydraulic structures, such as dams, canals and aqueducts (Africa, Europe, the Middle East and the Far East).

In Europe there are public or associative institutions for the management of waterways and dykes, canals and flood protection works, such as Canal do Midi (17th century)-France, waterringues (before the 15 th century)-Holland.

Important sanitation constriction ocurred in the nineteenth century in London, German and North American cities. In Germany, the association of users-Ruhrverband-was created.

In the twentieth century, the creation of institutions for the management of waterways, and dams for flood control and transposition of water between basins took place, highlighting the Company of the Rhone (France)—1933, and TVA—Tennessee Valley Authority_1933. 
Water resource management models vary in legal and administrative structure, cultural traditions, level of economic development and the conditions of water availability of each country. In federated states, different models of administration coexist. In turn, humid countries, where the availability of water is abundant, bureaucratic models are evident.

In Europe, private or public-private type associations, such as Germany and the Netherlands, basin committees and agencies in France, water authorities in England, Wales and Italy, and in Spain the Hydrographic Confederation (structures under state supervision)

In the United States (a) State Management of Water Resources (exception-indigenous areas with federal management); (b) East American (wet)—water management by regulatory instruments; (c) West American (dry) - water management, incorporating economic tools, with reduced state participation-Colorado Water Market, and the Drought Water Bank in CA).

The transitions in the way states act have changed significantly, leading to changes in the arrangements of their interventions. In this context, there is a need to change the standard of action, making regulatory intervention an essential instrument of public policy-Carvalho et al. (2017).

In Latin America, there are three ways of water governance in their environmental policies, that is, community management (Ecuador), social control (Venezuela) and social participation (Brazil), the latter inspired by the French model. In Mexico, the National Water Council-management from river basins as in Brazil. In Chile, the Water Rights Market Model.

The water governance in Brazil begins with the conceptual, theoretical and operational building in the National Water Resources Policy, through Law n\# 94331997 (Brasil 1934).

According to Souza Júnior et al. (2017), public authorities prepared most of the current affluent river plan and, consequently, most of the programs analyzed present proposals with regional divergences in their different planning scales and present failures in the synergy between the actions of the various proposals.

Cerezini et al. (2017) in studies developed by the Integrated Water Resources Management System of the State of São Paulo and on the institutional websites of the River Basin Committees, found that the Water Resources Management Units had Basin Plans and Status Reports, but many of these documents were outdated or absent for consultation in the system.

According to Rogers and Hall (2003), the notion of satisfactory governance starts with the following principles: Participation, transparency, equity, accountability, ethics and sustainability.

(a) Participation: All citizens, directly or through representatives in all stages of the formulation process, as well as in decision-making spaces. This requires the government to act, at all levels, from an inclusive approach.

(b) Transparency: Information should flow democratically within society. The different processes and decisions should be transparent and susceptible to criticism.

(c) Equity: All social groups should have the opportunity to improve access to common goods.

(d) Responsibility: Government organizations, the private sector and civil society must be accounted for the interests they represent.

(e) Consistency: The increasing complexity of issues related to water resources requires appropriate and coherent policies.

(f) Sensitivity: Institutions and processes must meet all and respond appropriately to the necessary changes.

(g) Integration: Water governance should promote comprehensive and holistic approaches.

(h) Ethics: Water governance must necessarily be sitting on ethical principles that underlie the societies in which it is applied.

(i) Sustainability: Requires in its applicability an ecosystem vision, for the maintenance of aquatic ecosystems is essential for continuity of life (Rogers and Hall 2003).

The sustainability of territorial spaces is not easy, especially in regions which depend on others, as it is difficult to estimate the demand for the natural resource. 
This interdependence is greater than the spatial scale of analysis; for example, a country tends to be more self-sustaining in resources than a small watershed. To be clearer, one can say that a territorial space is sustainable "if it can maintain the balance between supply and demand for natural resources" (Mariotoni and Alberto 2000).

Santilli (2007) reveals that several Treaties and International Declarations (especially the Declaration of Dublin, Ireland, 1992) have stated decentralization expressly in the management of water resources, to harmonies participatory integration of public management boards, private and citizens interested in the use and conservation of water.

\subsection{The Policy of Water Resources in Brazil}

The management of water resources is not a recent phenomenon in Brazil, but it is associated with Portuguese colonization (De Fonseca and Do Prado Filho 2006).

The Imperial Constitution in 1824 defined Brazil's independence and did not address the protection of water. Article 162 of the Penal Code of 1890 addressed water protection with the right to safe health [4].

The Civil Code of 1916 mentioned water, only regulating the right of use concerning the right neighborhood. Water was considered of limited economic value and private domain (Parlamento Europeu 2019).

The Federal Constitution of 1934 provides in its article 5, subsection XIX, letter "j" Racing the Union privately to legislate on water (Brasil 1988).

In 1934, the National Congress of Brazil, through Decree 24643 promulgates the Code of Waters (Brasil 1934). The first legal instrument was disciplining the planning and management of water resources of the Republic. It addressed water types, forms of exploitation, measures in case of contamination of water bodies, criteria for the use of water by industries. Costa e Silva et al. (2017) considered that the Water Code aimed to empower the Ministry of Agriculture to protect water resources, noting the agricultural vocation of the country.

The 1946 Constitution defined the water as a state and union property. The lakes and streams in Union land, which cover more than one state, also work as a border for other countries or which extended to another foreign territory, were considered to be assets of the Union. The states had in their lakes and rivers domain on state land and with sources in the province (Resende 2019).

Within the following decades, especially with the occurrence of environmental movements, it became the Brazilian Federal Constitution of 1988 with the prospect of the creation of the National System of Water Resources Management. The Brazilian Constitution of 1988 introduced the chapter on the environment (Brasil 1988), the Federal Law 6938 of 1981 establishing the national environmental policy (Brasil 1981).

Art. 225. Everyone has the right to an ecologically balanced environment and of common use and essential to a healthy quality of life, imposing to the government and society the duty to defend it and preserve it for present and future generations. (Brasil 1988)

The constitutional guidance of 1988 and the report of the International Conference on Water Resources and Environment played an important role so that in 1997 a federal law \# 9433 could be approved, establishing the national water policy. In 1998 came the Environmental Crimes Law (Brasil 1998). Carvalho et al. (2017) well exposes water legislation.

The reports of the National Water Agency_Agência Nacional de Águas_ANA (2018b), from a conference held in Dublin, highlighted four basic principles: (a) The effective management of water resources should cover surface and groundwater resources, always with the river basin as the basic unit of development; (b) The development and management of water resources should be based on a participatory perspective, involving users, planners and policymakers at all levels (c) Women have a central role in managing the provision and protection of water (d) Water has an economic value in all its competing uses and should be recognized as an economic good. 
The guiding principles of the Brazilian law, well influenced by the preceding are the foundations necessary for its implementation:

Art. 1 The National Water Resources Policy is based on the following grounds: I-water is a public good; II-Water is a limited natural resource with economic value; III-in situations of scarcity, the priority use of water resources for human consumption and watering livestock; IV-the management of water resources should always provide the multiple uses of water; $\mathrm{V}$ - the river basin is the territorial unit for implementation of the National Water Resources Policy and activities of the National Water Resources Management System; VI-the management of water resources should be decentralized and include the participation of the Government, (sic), users and communities. (Brasil 1997)

Such foundations have enabled the design of five planning tools and fundamental water management: Water resources plan, grant use of water, collection, classification and information system:

Art. 5. The instruments of the National Water Resources Policy:

I-Water Resources Plans;

II-The framing of bodies of water into classes, according to the main uses of water;

III-The granting of water use rights;

IV—Charging for the use of water resources;

V-The Water Resources Information. (Brasil 1997)

The water resources plan aimed at making diagnosis and prognosis, are being developed at the federal, state and river basin level. According to Agência Nacional de Águas-ANA (2018a) until the end of 2017, 158 plans of state watersheds were prepared in 16 Federative Units and 32 plans were under preparation in 10 Federative Units (Acre, Bahia, Espírito Santo, Minas Gerais, Mato Grosso, Pernambuco, Paraná, Rio Grande do Sul, Santa Catarina and São Paulo).

The frame bodies of water refer to the classification of water courses into classes, having the desired predominant use. According to Agência Nacional de Águas-ANA (2018b) in 2017, Brazil had 1625 quality monitoring water points in all Brazilian states. The classes were defined by 357 in CONAMA: Special, 1, 2, 3, and 4 .

The grant corresponds to the right of a certain volume use for a specified time, and it can also be earned for effluent discharge. According to Agência Nacional de Águas-ANA (2018a), within the set of federal units of Brazil, more than 75,000 licenses were issued and found to be valid on July 2017, for a total flow of more than $2.5 \mathrm{~m}^{3} / \mathrm{s}$.

The charge relates to the taxation of the use of water as a resource of nature for the withdrawal or the quality of effluent released. It aims to encourage the rational use of water and guarantee funds for investments in the watershed.

Finally, the information system aims to train and qualify the agents involved in the process, as well as the community.

Established was the National System of Water Resources Management-SINGREH where state, municipal and national boards are involved. However, the full power was directed to the union and the states to legislate within the established limits of competence.

Art. 33. Integrate the National System of Water Resources Management:

I-The National Water Resources Council;

II-The Water Resources Councils of the States and the Federal District; 
III-Committees of the basin;

IV-The public federal, state and municipal board, in which responsibilities relate to the management of water resources;

\section{V-Water Agencies. (Brasil 1997)}

Special emphasis should be given to river basin committees that are real "water parliaments", performing decentralized and participatory management, and the basin agencies, operational support of the deliberations. According to Agência Nacional de Águas_ANA (2018b), there are already nine committees of federal watersheds and 224 state watersheds.

In 2000, the National Water Agency was created according to Law \# 9984 (Brasil 2000) the board responsible for the coordination and discipline in planning and management of water resources; In 2018 , the provisional measure adds to this board's normative role of national character in the provision of public sanitation services.

This also provides for the creation of the National Water Agency-ANA, a federal entity implementing the National Water Resources Policy, coordinating the National System of Water Resources Management and responsible for the establishment of national reference standards for regulating the provision of public services sanitation (Brasil 2018). The following year, the National Water Resources Council established the National Hydrographic Division into 12 regions (Figure 1), according to the resolution n.32 of October 15th, 2003 (Brasil 2003).

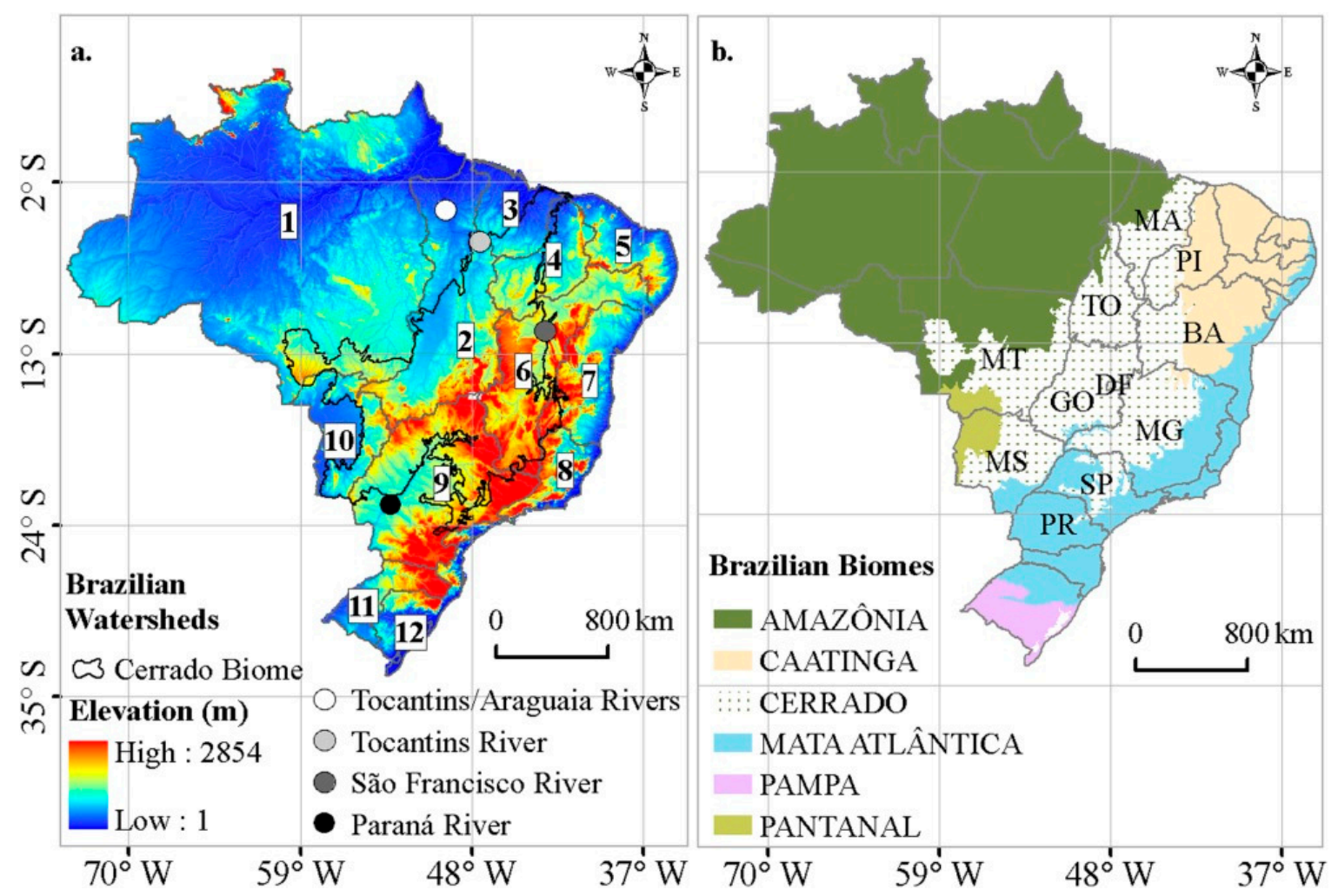

Figure 1. (a) Brazilian Watersheds and (b) Brasilian Biomes. Hydrographic Regions of Brazil: (1) Amazon; (2) Tocantins; (3) Western Northeast Atlantic; (4) Parnaíba; (5) Eastern Northeast Atlantic; (6) San Francisco; (7) East Atlantic; (8) South-East Atlantic; (9) Paraná; (10) Paraguay; (11) Uruguay; (12) South Atlantic. Fluviometric stations represented by circles. B. Biomes. Source: Oliveira et al. (2014).

In 2005 the National Environment Council-CONAMA issued resolution n. 357 (Brasil 2005) which established a standards framework of water bodies and sewage discharge. With subsequent 
amendments, in 2011 the standard of effluent discharge is redefined by CONAMA resolution n. 430 (Brasil 2011).

Another important milestone refers to the year 2007, with the creation of the Federal Law \# 11,445 (Brasil 2007), a national sanitation policy, considering the set of services, infrastructure and water supply facilities, sanitation, urban sanitation, management of solid waste and drainage of urban rainwater, also restated by Provisional Measure n. 868, (Brundtland 1987).

In 2017 Consolidation Ordinance No. 5. It established a national guideline for basic sanitation, created the Sanitation Interministerial Committee Basic, which amended Law \#. 6,766, of December 19, 1979, Law \# 8,036, of May 11, 1990, Law \# 8666 of 21 June 1993, and Law \# 8,987, of February 13, 1995, and repealing Law \# 6528 of 11 May 1978 (Brundtland 1987). In 2019, changes within the administrative structure of the Federal Government were transferred to the National Water Agency-ANA's Ministry of Environment to the Ministry of Regional Development, which started a new stage in the management board, but also received criticism from social organizations.

Forms of financial compensation were also introduced, those that preserve water springs, water resources or possess properties that provide environmental services expressed in the forest code, law \# 12.651, of May 25th, 2012 (Brasil 2012).

\subsection{The Policy of Water Resources in Italy}

There has been great concern about water for quite some time, that's why the Royal Decree n. 264 of August 10th, 1884, had already established some discipline over the water (Italy 1884).

Subsequently, the Italian Constitution in Article 117 states:

The legislative power of the Member States and the Region of the Constitution risks as well as the bonds arising from the community and international obligations. (Itália 1947)

The state shall exercise exclusive legislation in certain issues, especially aspects related to environmental problems.

s) protection of the environment, the ecosystem and cultural heritage. (Itália 1947)

Similarly, Italy has its regulatory mechanisms. The following are important moments in the planning and management of water resources in Italy.

In 1989, the law 183 established the "Basin Authorities" joint body (Italy 1989), agreed to among states and regions, operating in the watershed, considered planning and management units in defense of the soil and subsoil, the use and management water resources, regardless of the administrative subdivisions, that is, watersheds are considered inseparable physical units in which is the diagnosis, prognosis and actions to protect, defend and improve existing resources.

This innovation within the legislation is evident throughout the efforts of Professor Giulio De Marchi, who chaired the committee in 1966, creating the prerequisites for an expanded and integrated view of planning and based on the watershed.

Data collection was performed, identifying rivers and basins, as well as development and implementation of projects, with limited operation by the resistance of local governments who wished to administer the territory more freely and without any authorization from "Basin Authorities".

The basin authority is consulted, locally, between institutions and entities involved in the planning and management of territorial unity, overcoming the fragmentation of skills and institutions that do not allow integrated and sustainable planning.

Bringing "basin authority" to life was and is a way to join all actions within the territory. By doing so, Italy was divided into river basins, with different territorial levels of importance: National, interregional, and regional.

Another important milestone is the law 36 of 1994 (Italy 1994). In essence, it highlights that the first item is that the protection belongs to the state, as well as concern for the rational use, ensuring to future generations the use of the resource. 
1. All surface and groundwater, even though not drawn from underground, are public and are a resource that is safeguarded and used following the criteria of solidarity.

2. Any use of water is carried out, safeguarding the expectations and rights of future generations to enjoy a full environmental heritage.

3. The water uses are intended to save and renew resources so as not to compromise water resources, environmental housing, agricultural, aquatic flora and fauna, geomorphology and hydrological equilibrium processes (Italy 1994).

This continues and reinforces the priority to the human being as a condition "sine qua non" the legal prerogative.

The use of water for human consumption has priority over other users of the same body surface or underground water. Other uses are permitted when the resource is sufficient and do not adversely affect the quality of water for human consumption. (Italy 1994)

They describe the procedures and actions aimed at promoting integrated water service and radical restructuring in funding sectors, distribution and treatment of water, replacing the existing aqueduct mosaics by networks whose dimensions and management was more current.

In 1999, Act 152 addressed the responsibility for water pollution (Italy 1999), an important point of view regarding quality. However, this new law had difficulties to be implemented, because it collided with the interests of organizations and production cost, the necessary measures for the quantitative and qualitative management of the water system, the regional and watersheds are part of it.

Concerned with the issue of water resources Directive 2000/60/EC of the European Parliament and of the Council of October 23rd, 2000, established a framework for community action within the field of water (Parlamento Europeu 2000).

For Machado (2018) the management system promoted from the Directive 2000/ 60 were based on the following principles:

1. The principle of integration, whereby systemic management must protect the entire surface and groundwater performed together with the management and sector or regional policies;

2. The principle that water management should be set on the hydrological unit watershed, not on political-administrative divisions;

3. The principle by which states and municipalities (or regions, provinces, counties, as used in Italy) should ensure good water quality, prevent degradation/pollution, reduce the amount of waste produced and to eliminate generation potentially hazardous waste;

4. The principle of joint work (including research) to avoid shortages and pollution of water based on the establishment of effluent emission limits and control of point and diffuse sources of release;

5. The principle of sustainability by seeking a use economically, ecologically and socially sustainable use of water resources;

6. The public cooperation principle for the creation of policies that provide participatory watershed management through active participation or consultation of stakeholders;

7. The principle of transparency concerning the use that is made of water (Bonus) and on the division of losses (Lien, costs and environmental damage) arising from these uses. In this case, it applies the principle of "polluter payer" (Machado 2018).

Among the instruments used in Italy, we highlight the River Contracts. These contracts are instruments of integrated management, territorialized and participatory water resources which are intended for the explicit purpose of execution, on a local scale, the goals are based on the European Policy Water 2000/60/EC (water Framework Directive/WFD) (European Commission EC, Machado 2018).

In Italy the legislative decree of April 3rd, 2006, n. 152 (Italy 2006) and subsequent amendments, work as an environmental code, and deal with the defense of the soil and fight against the waste; water pollution and water resources management. Articles 63 and 64 are inserted, respectively, by the basin 
authorities and hydrographic districts. It comprises standards for the "Trusteeship Plan of Water" (PTA2) approved on March 2007 by Decree 117-10731, which provides for the use of the instruments called "Negotiated Programming".

According to Machado (2018) The "River Agreements" were inserted within this set of instruments (Contratti di Fiume-CDF), established in Article 10, which aim to encourage the participation of all major subjects in the territory of the river basin to be managed for the definition and implementation of integrated actions in order to overcome the fragmented environmental vision.

Created was Directive 2007/60/EC of the European Parliament and of the Council of October 23th, 2007 relating to the assessment and management of flood risks, promptly backed in Italy by Legislative Decree February 23rd, 2010, n. 49 (Italy 2010b).

Provisions for environmental issues to promote a green economy and measures to curb the excessive use of natural resources have led to new legislation, and the art. 51 paragraph 2 of the Law of December 28th, 2015, n. 221, (Italy 2015) replaced in its entirety Articles 63 and 64 of Legislative Decree of April 3rd, 2006 establishing the basin plan as an important tool for planning and management of water resources. In article 64 defines the river basin (Figure 2).

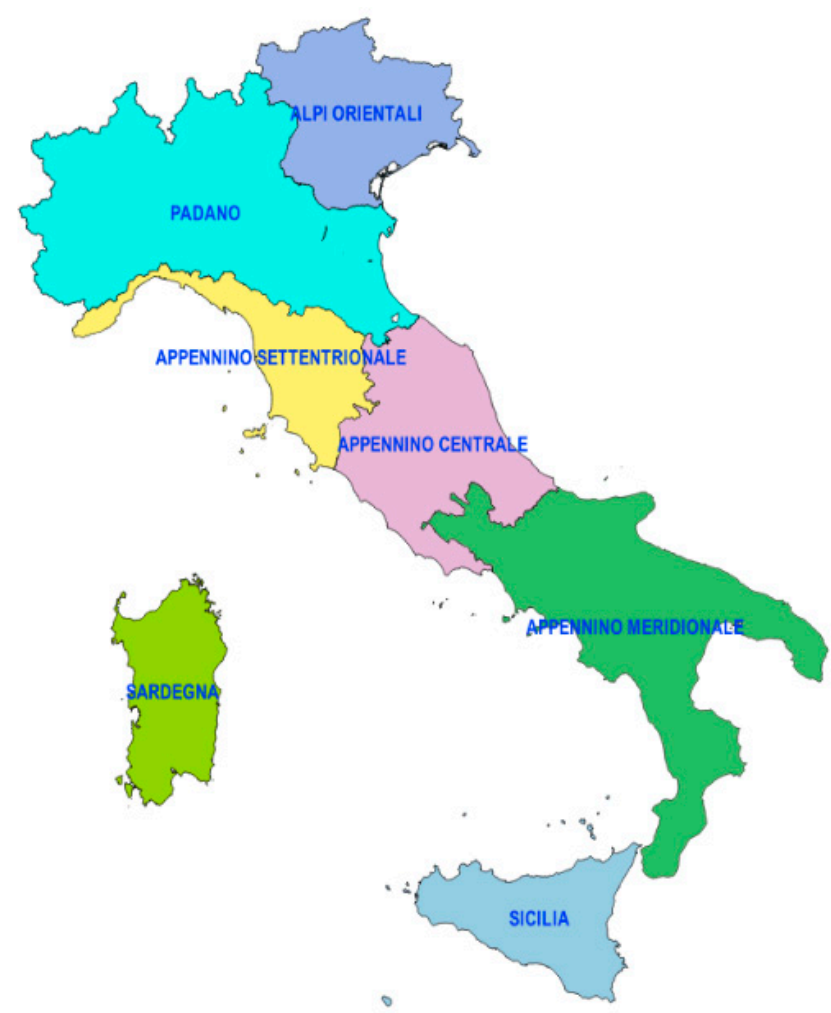

Figure 2. Districts or Hydrographic regions in Italy. Source: Italy, Law 221, (Italy 2015). Ministry of the Environment and the Protection of the Territory and the Sea, (Itália 2019).

The hydrographic districts extend to more than one basin at different national, inter-regional and regional levels or listed in quantity in brackets: Hydrographic District Alpiorientali (4); Hydrographic District Fiume Po (7); Hydrographic District Appennino Settentrionale (5); Hydrographic District Appennino centrale (8); Hydrographic District Appennino meridional (14); The river basin of Sardinia (1); Hydrographic district of Sicilia (1) (Italy 2015).

Subsequently, the Ministry of Environment Protection and Land and Sea of October 25th,2016 established allocation regulation and transferred to the district authorities of human and instrumental resources, including offices and financial institutions of the basin authorities (Italy 2016). To make it easier, to support and rationalize the use of public money, improve competitiveness and ensure more effective environmental protection. It established in 2008 the Institute for the Protection and 
Environmental Research-ISPRA, operating since 2010, with the decree of May 21st, 2010 n. 123 (Italy 2010a), which defines the fusion within ISPRA three entities controlled by the Ministry of Environment and Territorial Protection and the Sea.

The ISPRA has technical and scientific functions, both to support the Ministry of the Environment and for the protection of the territory and the sea, as well as directly through monitoring activities, evaluation, control, inspection and management, and environmental information. Dono et al. (Dono et al. 2015) describe the sustainable management of water resources in the face of climate change. Ferrante and Sciacca (Ferrante and Sciacca 2013) specify sustainable management of water resources in Italy.

Concern for water comes from the European Environment Agency in several studies (European Environmental Agency EEA, 2018b, Ferrante and Sciacca 2013), but Italy plays a key role. Created in 2017, was the National Environmental Protection System, a network that aggregates the institute, the 19 regional agencies (ARPA) and two autonomous provinces (APPA) and which ISPRA is coordinated, also in charge of cooperating with the European Agency environmental and another international environment.

In 2018 the Report Environment to the ISPRA (Instituto de Proteção e Pesquisa Ambiental_ISPRA 2018) expressed the efforts made in research on the subject and strengthened the Italian environmental system.

\subsection{Actions and Outlook}

In Brazil and Italy, actions were taken with the aim of monitoring the quality and quantity of water resources. In Brazil, the government play an executive role with their state and federal water resources plans, as well as river basin plans. In Italy, there is a predominant role of river basin assemblies, called river basin committees in Brazil, allowing self-management of social subjects/agents.

Table 1 shows a summary of the hydrographic regions in both countries, as well as an administrative organisation in 2019.

Table 1. Summary of the administrative and river areas in Brazil and Italy.

\begin{tabular}{|c|c|c|c|c|c|c|}
\hline Countries & $\begin{array}{l}\text { Geographic } \\
\text { Region }\end{array}$ & $\begin{array}{c}\text { Administrative } \\
\text { Region }\end{array}$ & State & Province & $\begin{array}{l}\text { Municipality or } \\
\text { Commune }\end{array}$ & $\begin{array}{c}\text { Region or } \\
\text { Hydrographic } \\
\text { District }\end{array}$ \\
\hline Brazil & 5 & - & $26^{a}$ & - & 5568 & 12 \\
\hline Italy & 4 & 20 & - & $107^{b}$ & 7926 & 7 \\
\hline
\end{tabular}

Source: The author based on data Database county (Database Comuni 2019); Brazil (Brasil 2003): Italy (Italy 2015): Instituto Brasileiro de Geografia e Estatística-IBGE (2018) ${ }^{a}=26$ states and one Federal District; ${ }^{b}=$ The Italian territory is divided into 107 territorial areas and 100 administrative bodies of the second level ( 80 provinces, 14 cities and metropolitan six free municipal consortia in Sicily) two autonomous provinces of Trentino-Alto Adige.

Brazil and Italy organized a national water resources system that allows the construction of information networks and inter-sectoral coordination, especially ANA and ISPRA entities, respectively, within federal bases. In both countries, the main challenges are fighting water pollution, rational use, mitigate drought, prevention of critical situations; and having contingency plans if necessary.

Water quality is an aspect that the Brazilian legislation which includes the effluent discharge standards in CONAMA 430 resolution (Brasil 2011) as the possibility of granting the qualitative aspect of water; without considering, of course, the laws that define standards of potability of water for public supply in the order of the Ministry of Health n. 5 (Brasil. Ministério da Saúde 2017). In Italy, the Legislative Decree 31 (Italy 2001) establishing standards of water potability, while the Legislative Decree 152 (Italy 2006) deals with the planning and management of water resources.

Special attention is given in the case of Brazil facing events of drought that compromise the water supply in regions, such as in the Northeast, where drought generates constant fires, with atmospheric emissions, with synergistic effects on neighboring and diffuse countries across the globe.

For Souza Júnior et al. (2017), the semi-arid region suffers from the low implementation of the affluent river basin committees and the basin as a whole suffers from the lack of an appropriate mechanism for producing, updating and sharing information relevant to water management. 
Water security plans should be developed and operated. Mechanisms for granting and collection of water use as a natural resource must be improved. Already being discussed the is the possibility of a collective grant as a tool for user participation. Is important that warning systems may be inserted within laws or even water resources plans. Consorzio Alp Water Scarce (Consorzio Alp Water Scarce 2011) reports that the establishment of early warning systems against a shortage of water resources should be included in this law.

Recently, the change of the National Water Agency-ANA to the Ministry of Regional Development, out of the Ministry of Environment was not well received by environmental groups, regardless of having received powers to set policies aimed at the affluent. Movement of civil society organisation, called the National Observatory for the Rights to Water and Sanitation was created in 2019 to act in defense of water and promotion of sanitation in Brazil.

The European Parliament (Parlamento Europeu 2019) describes that the European Framework Directive Water is complemented by specific directives, such as groundwater, drinking water, bathing water, nitrate, wastewater, the environmental quality standards and floods. The European strategy on water resources objectives: (a) To protect and improve the water quality of aquatic ecosystems; (b) ensure the availability of a proper amount of water whenever and wherever needed, and finally; (c) promotes sustainable water use based on long-term management.

Planning and management should be supported on key principles, such as (a) water is a public asset; (b) the balance between supply and demand, considering the ecosystem support capacity; and (c) the quality and quantity of water are a priority to human life.

Inspections are essential from the perspective of conservation and monitoring of water resources., to enable the above command and control instruments, such as legislation. The polluter-payer principle should be applied to those who insist on disrespecting the laws and the natural balance. Futhermore, special attention should be given to preserving-recipient principle to exercise the stimulus function to the practices of making an available greater supply of water as well as better quality.

Vidale et al. (2012) discuses the payment for environmental services in Italy. In Brazil, the law \# 9605 of February 12th, 1998, established punishment for causing environmental damage, considering it a crime (Brasil 1998). Mechanisms for collecting water as a resource of nature and not just payment for treatment performed has set an important source of money for the operation of basin agencies and serving the educational process to users. It also adds increased stimulation to preserver-recipient principle makes up for those payments that improve environmental services, especially with producer program of water.

Cost reduction, optimization of resources, integration and territorial focus in the watershed are targeting strategies focused on planning and management of water resources. Below is a list of priority actions within the European Union, as well as its members, in the case of Italy:

- Improve the implementation of legislation;

- The integration of environmental concerns into other sectoral policies;

- Inducing the market to work for the environment;

- Participation and civic responsibility;

- More ecological planning and land management;

- High level of protection;

- The precautionary principle;

- preventive action;

- Damage correction to the principal source of the polluter pays;

- Integration of this policy into other community policies;

- Use of scientific and technical data currently available;

- Variability of environmental conditions in the community regions;

- Cost/benefit socio-economic development of the community;

- International cooperation—subsidiarity (Dalmiglio 1999). 
Recently in Italy, the Ministry of Environment and Land and Sea Protection, through the 2019-2021 report, shows us ways to identify policy priorities and actions to be performed.

Support and implement the commitments and agreements made at European and international level for sustainable development; strengthen and systematize policies and programs on climate and energy, with special attention to sustainable mobility and energy saving; increase the protection of terrestrial biodiversity and the Mediterranean and ensure better and more coordinated management of protected areas and natural capital; strengthen measures to combat hydrogeological instability, improving the protection of water resources to be valued as a common good and a universal human right, to fight the consumption of the; enhance the security of the territory, recovery activities and environmental rehabilitation of contaminated areas, as well as prevention and contrast of environmental damage and the country fires of lands; increase the effectiveness and the technical work on the work permits and environmental assessments, strengthen the relative transparency and participation system for citizens; improving waste management, to focus on reducing its production, promote a circular economy, strengthen measures to prevent and combat pollution, with particular attention to air quality; reset and prevent infringement procedures concerning environmental issues, strengthening the participation of the system in EU policies, ensure correct implementation of projects and programs financed with European funds. (Itália 2019)

Held in 2018 for the first time, was the World Water Forum in Brasilia, Brazil, in its eighth edition. At the time, the National Water Agency-Agência Nacional de Águas-ANA (2018a) presented the legacy project with 20 proposals for improvement of the constitutional frameworks, legal and infra-legal of water management in Brazil. The deliberations of the Forum, the highlights are the ten principles that become part of the Citizen Forum Legacy:

Principle 1-water is a community well, and a right of all beings and is essential for the guarantee of life in all its forms;

Principle 2-water management must be committed to the eradication of water-borne diseases, conflict and poverty, prevailing to the supremacy for the lives of people and nature over any other development interests.

Principle 3-the water should be ensured in quality and quantity through shared management.

Principle 4-decision making in water management underpinned on the ecosystem paradigm in preventive and disaster management and pollution.

Principle 5-the effective participation of society in water management depends on access to information, education quality and power in decision-making spaces and must then include the creation of enabling environments that encourage.

Principle 6-countries should strengthen and ensure effective participation and social control in water management, developing mechanisms, procedures and policies with the inclusion of traditional communities.

Principle 7-water governance should be cooperative, transparent and integrated management of groundwater and surface water in watersheds.

Principle 8-the shared water management should be strengthened with the completion of joint constant in the relationship between the public and private sectors and civil society.

Principle 9-water culture must be preserved by all and must be harmonized with the economy from the different environmental contexts. 
Principle 10-as a seed for the future, water management in all its aspects should consider women and young people in all its fullness. (Fórum Mundial da Água 2018)

These principles guide the focus of global policies on water resources, but it does not extinguish itself, because it demands concrete actions to be executed.

Regarding the methodological approach, innovation in the management of water resources and water services is not only about technological innovation, but also stems from the innovation of reference markets and innovation of the rules. In the case of markets, for example, manufacturing companies will have to adapt not to sell just "products", but "services" based on their products. As seen below, it shows the importance of a strong collaboration between different skills, an open innovation logic, between technology providers, research, final users and policymakers (De Carli 2017).

According to Souza Júnior et al. (2017), it is necessary to improve the mechanism of articulation between the plans with the use of integrated assessment tools and decision-making context, strengthen public participation through committees of affluent rivers and the adoption of a collaborative data platform from which to share information generated in different sectors of society.

Lima et al. (Lima et al. 2014) propose an analysis engine as a "governance thermometer" of actions in water resources, organized into five areas:

A: Institutional Environment (effectiveness of the law and importance of the issue to the public agenda);

B: State capabilities (financial resources and quality of bureaucracy);

C: Management Instruments (planning, targets, monitoring, indicators and evaluation of public policies);

D: Intergovernmental Relations (inter-sectoral and intra-sectoral coordination, municipal participation in the system and federal forums);

E: Interaction State Society (qualification and participation channels) (Lima et al. 2014).

Finally, the 9th World Water Forum will take place in Dakar, Senegal in 2021 addressing "Water Security". Until then, many actions within water defense will be made to benefit humanity.

\section{Conclusions}

It appears that there are directives, standards and laws governing planning and water resources management in Brazil and Italy. The concern is long-standing, but it has intensified, due to higher risks of pollution and climate change that has affected the rainfall and water availability.

The growing need for public policies for the preservation and conservation of water resources has enabled the shared management, committees and preparation of watershed plans. Other important instruments have been implemented, but attention should be given to policies that stimulate the conservative-recipient principle like the "water producer", without affecting the polluter-payer principle

The main destination of water in both countries within the agricultural sector should be of great concern in order to not affect other uses, as well as the development of technologies that improve the efficiency in this and other sectors.

The definition of sustainability as "development that meets the needs of the present without compromising the ability of future generations to meet their needs" (Brundtland 1987), are the rights of future generations that will be benefitted by this precious commodity. If we do not do it using the knowledge and understanding of science, then we must do it by penitence, in respect to the teachings of human solidarity.

The responsibility belongs to everyone, including the government, businesses, consumers, producers, research institutions, class entities and other institutions of civil society, therefore, contributing to the reduction of environmental impacts of the use of water resources of the planet.

Evaluating the various constitutional texts existing in countries with consolidated democracies, the defense of the environment is anthropocentric, and the norms of protection of water resources are merely programmatic (Muro 2018). 
Given the urgent shortage of water for the population, there is an urgent need to develop stricter rules to control the consumption of natural resources that are fundamental for the maintenance of all life on the planet.

The constitutional norms must be altered so that the obligation to maintain the hydric system of each country is imposed, going from the quality of merely programmatic norms to constitutional norms of contained efficacy, so that the ordinary environmental legislator is directed to create norms of protection of the efficient hydric resources and with prevision of stronger penalties so that not to guarantee the environmental status quo of the hydric health of the country (Muro 2014).

Furthermore, the concept of aerial rivers was not observed in the articles and in the doctrine analyzed, a concept that should be included in environmental standards, since it is an important means of preserving the volumes of water systems, regardless of their size.

Finally, the concept of mitigating the use of natural water resources in production processes must be reviewed, imposed by the environmental legislator, which remains inert, avoiding interfering in production processes, determining the gradual reduction of drinking water and the inclusion, through regulatory orders, of the reuse of water in cleaner production processes and circular economy.

Author Contributions: Conceptualization, A.P.; Methodology, A.P.; Validation, A.M.J.; Formal Analysis, A.M.J.; Investigation, A.P.; Resources, A.P.; Data Curation, A.P.; Writing-Original Draft Preparation, A.P.; Writing-Review and Editing, A.M.J.; D.L.P.; Visualization, D.L.P.; A.M.J. and M.R.; Administration, A.M.J.; Funding Acquisition, A.M.J. Supervision: A.M.J. Authorship must be limited to those who have contributed substantially to work reported.

Funding: This research received no external funding.

Acknowledgments: The first and the last authors acknowledges the support of Fundação de Amparo à Pesquisa do Estado de Goiás - FAPEG.

Conflicts of Interest: The authors declare no conflict of interest. The funders had no role in the design of the study; in the collection, analyses, or interpretation of data; in the writing of the manuscript, and in the decision to publish the results.

\section{References and Notes}

Agência Nacional de Águas-ANA. 2018a. Conjuntura de Recursos Hidricos No Brasil; Brasília: ANA.

Agência Nacional de Águas-ANA. 2018b. Projeto Legado. 20 propostas para aperfeiçoamento dos marcos constitucional, legal e infralegal da gestão de águas no Brasil—Preparação para o $8^{\circ}$ fórum mundial da água. Available online: http://www3.ana.gov.br/portal/ANA/programas-e-projetos/projeto-legado-1/projetolegado/documento-base-versao-1-0-6-dezembro-2017.pdf (accessed on 3 June 2019).

Brasil. 1981. Lei 6938 de 31/08/1981. Dispõe sobre a Política Nacional do Meio Ambiente, seus fins e mecanismos de formulação e aplicação, e dá outras providências. Available online: http://www.planalto.gov.br/ccivil_03/ Leis/L6938.htm (accessed on 6 June 2018).

Brasil. 1988. Constituição de 1988. Presidência da República: Casa Civil. Available online: http://www.planalto. gov.br/ccivil_03/constituicao/constituicao.htm (accessed on 3 June 2019).

Brasil. 1997. Lei 9433 de 8/01/1997. Institui a Política Nacional de Recursos Hídricos, cria o Sistema Nacional de Gerenciamento de Recursos Hídricos, regulamenta o inciso XIX do art. 21 da Constituição Federal e altera o art. $1^{\circ}$ da Lei $n^{\circ} 8.001$, de 13/03/1990, que modificou a Lei $n^{\circ} 7.990$, de 28/12/1989. Available online: http:// www2.camara.leg.br/legin/fed/lei/1997/lei-9433-8-janeiro-1997-374778-publicacaooriginal-1-pl.html (accessed on 17 May 2019).

Brasil. 1998. Lei n. 9.605, de 12/02/1998. Dispõe sobre as sanções penais e administrativas derivadas de condutas e atividades lesivas ao meio ambiente, e dá outras providências. Available online: http://www.planalto.gov.br/ ccivil_03/leis/19605.htm (accessed on 5 June 2019).

Brasil. 2000. Lei n. 9.984, de 17/06/2000. Dispõe sobre a criação da Agência Nacional de Águas-ANA, entidade federal de implementação da Política Nacional de Recursos Hídricos, de coordenação do Sistema Nacional de Gerenciamento de Recursos Hídricos e responsável pela instituição de normas de referência nacionais para a regulação da prestação dos serviços públicos de saneamento básico. Available online: http://www.planalto.gov.br/ccivil_03/Leis/L9984.htm (accessed on 20 June 2019). 
Brasil. 2003. Conselho Nacional de Recursos Hídricos. Resolução 32, 15/10/2003. Institui a divisão hidrográfica do Brasil. Available online: http://www.cnrh.gov.br/divisao-hidrografica-nacional/74-resolucao-n-32-de-15-deoutubro-de-2003/file (accessed on 16 May 2019).

Brasil. 2005. Conselho Nacional de Meio Ambiente. Resolução 357. Dispõe sobre a classificação dos corpos de água e diretrizes ambientais para o seu enquadramento, bem como estabelece as condições e padrões de lançamento de efluentes, e dá outras providências. Data da legislação: 17/03/2005—Publicação DOU n ${ }^{\circ} 053$, de 18/03/2005. pp. 58-63. Available online: http://www2.mma.gov.br/port/conama/legiabre.cfm?codlegi=459 (accessed on 20 June 2019).

Brasil. 2007. Lei 11.445, de 5 de janeiro de 2007. Estabelece as diretrizes nacionais para o saneamento básico, cria o Comitê Interministerial de Saneamento Básico. Available online: http://www.planalto.gov.br/ccivil_03/ _ato2007-2010/2007/lei/111445.htm (accessed on 20 May 2019).

Brasil. Conselho Nacional de Meio Ambiente. 2011. Resolução 430 de 13/05/2011. Dispõe sobre condições e padrões de lançamento de efluentes, complementa e altera a Resolução n. 357, de 17 de março de 2005, do Conselho Nacional do Meio Ambiente-CONAMA. Publicação DOU nº 92, de 16/05/2011, p. 89.

Brasil. 2012. Lei $n^{\circ} 12.651$, de 25/05/2012. Dispõe sobre a proteção da vegetação nativa; altera as Leis nos 6.938, de 31 de agosto de 1981, 9.393, de 19 de dezembro de 1996, e 11.428, de 22 de dezembro de 2006; revoga as Leis nos 4.771, de 15 de setembro de 1965, e 7.754, de 14 de abril de 1989, e a Medida Provisória n 2.166-67, de 24 de agosto de 2001; e dá outras providências. Available online: http://www.planalto.gov.br/ccivil_03/_ato20112014/2012/lei/112651.htm (accessed on 5 June 2019).

Brasil. Ministério da Saúde. 2017. Portaria de consolidação n 5, de 28/09/2017. Consolidação das normas sobre as ações e os serviços de saúde do Sistema Único de Saúde. Available online: http://portalarquivos2.saude.gov.br/ images/pdf/2018/marco/29/PRC-5-Portaria-de-Consolida----o-n---5--de-28-de-setembro-de-2017.pdf (accessed on 3 June 2019).

Brasil. 2018. Medida provisória n. 868 de 27/12/2018. Atualiza o marco legal de saneamento básico e dá outras providências. Available online: http://www.planalto.gov.br/ccivil_03/_Ato2015-2018/2018/Mpv/mpv868.htm (accessed on 24 May 2019).

Brasil. 1934. Decreto n. 24.643, de 10/06/1934. Código das águas. Available online: http://www.planalto.gov.br/ ccivil_03/decreto/d24643.htm (accessed on 3 June 2019).

Brundtland, Gro Harlem. 1987. Our Common Future-The World Commission on Environment and Development. Oxford: Oxford University Press.

Carvalho, Bruno Eustáquio Ferreira de Castro de, Rui Cunha Marques, and Oscar Cordeiro Netto. 2017. Regulatory Impact Assessment (RIA): From the State of Art until Conceptual and Framework Proposal Model. Journal of Contemporary Management 6: 111-26.

Cerezini, Monise Terra, Flávia Darre Hanai Barbosa, and Frederico Yuri. 2017. Instruments of water resources policy in São Paulo state: Current situation and prospects. Revista Brasileira de Geografia Física 10: 499-511. [CrossRef]

Consorzio Alp Water Scarce. 2011. La gestione delle risorse idriche e la scarsità d'acqua nelle Alpi: Raccomandazioni per $i$ gestori delle risorse idriche e per gli amministratori. Chambéry: University of Savoie.

Costa e Silva, Danilo, Gesinaldo Candido, José Baracuhy, Henrique Chaves, and Wilson Curi. 2017. Gestão de recursos hídricos no Brasil e interdisciplinaridade: Uma reflexão entorno de apontamentos contemporâneos desta relação. Revista Espacios 38: 4-15.

Dalmiglio, Alessandro. 1999. La normativa europea e nazionale in materia di risorse idriche. Ruolo di arpa lombardia e prospettive operative. ARPA Lombardia, Settore Risorse idriche e naturali. Available online: https://www.arpalombardia.it/sites/DocumentCenter/Documents/DALLA\%20LEGGE\%20MERLI\% 20Dlgs\%20\%20152\%201999\%20E\%20SUCCESSIVE\%20MODIFICHE\%20\%20DISCIPLINA\%20DEGLI\% 20SCARICHI\%20E\%20TUTELA\%20DELL\T1\textquoterightAMBIENTE/dalmiglio.pdf (accessed on 16 May 2019).

Database Comuni. 2019. Database ed elenco dei comuni italiani 2019 Aggiornato. Available online: https: //www.databasecomuni.it/elenco-dei-comuni-italiani-aggiornato-al-2019/ (accessed on 5 June 2019).

De Carli, Alessandro. 2017. La multidisciplinarietà dell'innovazione a tutela delle risorse idriche. CERTeTUniversità Bocconi e Fondazione AquaLAB. Ingegneria dell'Ambiente 4: 107-8. 
De Fonseca, Alberto de Freitas, and José Francisco Do Prado Filho. 2006. Um importante episódio na história da gestão dos recursos hídricos no Brasil: O controle da Coroa Portuguesa sobre o uso da água nas minas de ouro coloniais. Revista Brasileira de Recursos Hídricos 11: 5-14. Available online: https://www.abrh.org.br/ SGCv3/index.php?PUB=1\&ID=23\&SUMARIO=340 (accessed on 3 June 2019). [CrossRef]

De Macedo, Jorge Antônio Barros. 2007. Águas e águas. 3a . Edição. Belo Horizonte: CRQ.

Dono, Gabriele, Raffaele Cortignani, Davide Dell'unto, and Graziano Mazzapicchio. 2015. Gestione sostenibile delle risorse idriche: Efficienza e cambiamenti climatici. Agriregionieuropa anno 11 41: 12-15.

European Commission (EC). Commission Staff Working. 2007. Document Accompanying Document to the Communication from the Commission to the European Parliament and the Council Towards Sustainable Water Management in the European Union First Stage in the Implementation of the Water Framework Directive 2000/60/EC; Copenhagen: European Environment Agency.

European Environmental Agency (EEA). 2018a. Signals in 2018. Water Is Life. Available online: https://www.eea. europa.eu/publications/eea-signals-2019-land/at_download/file (accessed on 16 May 2019).

European Environmental Agency-EEA. 2018b. Water Exploitation Index. Available online: https://www.eea. europa.eu/data-and-maps/indicators/use-of-freshwater-resources-2/assessment-3 (accessed on 14 May 2019).

Ferrante, Margheritta, and Salvatore Sciacca. 2013. Gestione delle risorse idriche in Italia. Roma: Società Editrice Universo. SEU.

Fórum Mundial da Água. 2018. Documentos. Available online: http://8.worldwaterforum.org/pt-br/documents-0 (accessed on 3 June 2019).

Instituto Brasileiro de Geografia e Estatística-IBGE. 2018. IBGE atualiza lista de municípios e distritos do Brasil. Available online: ftp://geoftp.ibge.gov.br/organizacao_do_territorio/estrutura_territorial/divisao_territorial/ (accessed on 5 June 2019).

Instituto de Proteção e Pesquisa Ambiental—ISPRA. 2018. Rapporto Ambiente—SNPA Edizione 2018. Available online: https://www.snpambiente.it/2019/02/27/rapporto-ambiente-snpa-edizione-2018/ (accessed on 20 May 2019).

Italy. 1884. Regio Decreto n. 2644 del 10/08/1884. Disciplina delle acque pubbliche. Gazzetta Ufficiale del; Regno d'Italia, n. 227, s. $3^{\text {a }}, 13$ Settembre 1884.

Itália. 1947. Costituzione Della Repubblica Italiana. GU n.298 del 27-12-1947. Roma. Available online: https: //www.senato.it/documenti/repository/istituzione/costituzione.pdf (accessed on 20 May 2019).

Italy. 1989. Legge 18 maggio 1989, n. 183. Norme per il riassetto organizzativo e funzionale della difesa del suolo. (GU n.120 del 25-5-1989—Suppl. Ordinario n. 38). Available online: http://www.adbve.it/Documenti/legge18389.htm (accessed on 5 June 2019).

Italy. 1994. Legge 5 gennaio 1994, n. 36. Disposizioni in materia di risorse idriche. GU n.14 del 19-1-1994-Suppl. Ordinario n. 11. Available online: http://www.adb.basilicata.it/adb/pubblicazioni/vol1/Decreti/Parte2/ NormeNazionali/25.pdf (accessed on 20 May 2019).

Italy. 1999. Decreto Legislativo 11/05/1999, n. 152. Disposizioni sulla tutela delle acque dall'inquinamento e recepimento della direttiva 91/271/CEE concernente il trattamento delle acque reflue urbane e della direttiva 91/676/CEE relativa alla protezione delle acque dall'inquinamento provocato dai nitrati provenienti da fonti agricole. GU n.124 del 29-5-1999—Suppl. Ordinario n. 101.

Italy. 2001. Decreto Legislativo 02/02/2001, n. 31 Attuazione della direttiva 98/83/CE relativa alla qualita' delle acque destinate al consumo umano. (GU n.52 del 3-3-2001-Suppl. Ordinario n. 41).

Italy. 2006. Decreto Legislativo 03/04/2006, n. 152. Norme in materia ambientale. GU n.88 del 14-4-2006-Suppl. Ordinario n. 96.

Italy. 2010a. Decreto 21/05/2010, n. 123. Regolamento recante norme concernenti la fusione dell'APAT, dell'INFS e dell'ICRAM in un unico istituto, denominato Istituto superiore per la protezione e la ricerca ambientale (ISPRA), a norma dell'articolo 28, comma 3, del decreto-legge 25 giugno 2008, n. 112, convertito, con modificazioni, dalla legge 6 agosto 2008, n. 133. (10G0143) GU n.179 del 3-8-2010.

Italy. 2010b. Decreto legislativo 23/02/2010, n. 49. Attuazione della direttiva 2007/60/CE relativa alla valutazione e alla gestione dei rischi di alluvioni. (10G0071) GU n.77 del 2-4-2010.

Italy. 2015. Legge 28/12/2015, n. 221. Disposizioni in materia ambientale per promuovere misure di green economy e per il contenimento dell'uso eccessivo di risorse naturali. (16G00006) GU n.13 del 18-1-2016.

Italy. 2016. Decreto 25/10/2016, n. 245 Regolamento recante modalita' di determinazione delle tariffe, da applicare ai proponenti, per la copertura dei costi sopportati dall'autorita' competente per l'organizzazione e lo svolgimento delle attivita' istruttorie, di monitoraggio e controllo relative ai procedimenti di valutazione ambientale previste dal decreto legislativo 3 aprile 2006, n. 152. (16G00255) GU n.1 del 02-01-2017. 
Itália. 2019. Ministerio Dell'ambiente e Della Tutela Dell Territorio e Del Mare. Riforma della Governance dell'Acqua. Available online: https://www.minambiente.it/pagina/riforma-della-governance-dellacqua (accessed on 24 May 2019).

Lima, Ângelo José Rodrigues, Fernando Luiz Abrucio, and Francisco Carlos Bezerra e Silva. 2014. Governança dos recursos hídricos: Proposta de indicador para acompanhar sua implementação. São Paulo: WWF, Brasil: FGV.

Machado, G. 2018. Contratti di fiume: O exemplo italiano na gestão territorial dos recursos hídricos. In I Simpósio Nacional de Geografia e Gestão Territorial e XXXIV Semana de Geografia da Universidade Estadual de Londrina. Anais do I SINAGGET e XXXIV SEMAGEO. Londrina: Universidade Estadual de Londrina, Volume 1, pp. 469-91.

Mariotoni, Mariotoni, and Carlos Alberto. 2000. Demanboro. A gestão dos recursos hídricos em mega-cidades: Desafios da sustentabilidade econômico-ecológica. Available online: www.eco.unicamp.br/projetos/agua/ artigos.html (accessed on 10 June 2019).

Muro, Aldo, Jr. 2014. Politcs, normative systems and air pollution control instruments: Legal aspects. Revista da SJRJ $n^{\circ}$ 41-Edição Especial: 1964-2014—50 Anos do Golpe Militar—Special Issue: 1964-2010—50 Years of Military Coup. Rio de Janeiro: Justiça Federal do Rio de Janeiro.

Muro, Aldo, Jr. 2018. Ética e estrutura de direitos do meio ambiente natural e artificial. O meio ambiente é objeto ou sujeito de direitos? Uma reflexão fulcrada na ética e na filosofia das ciências naturais. Paraná: Revista Eletrônica de Investigação Científica e Tecnológica, vol. IV, n. 15, ISSN 2368-7482.

Oliveira, Paulo Tarso, Mark Nearing, Susan Moran, David Goodrich, Edson Wendland, and Hoshin Gupta. 2014. Trends in Water Balance Components across the Brazilian Cerrado. Available online: https://doi.org/10.1002/ 2013WR015202 (accessed on 1 June 2019).

Parlamento Europeu. 2000. Directiva 2000/60/CE do Parlamento Europeu e do Conselho de 23 de Outubro de 2000 que estabelece um quadro de ação comunitária no domínio da política da água; JO L 327 de 22.12.2000. Luxemburg: PubliCare, p. 1.

Parlamento Europeu. 2019. Protezione e gestione delle risorse idriche. Note sintetiche sull'Unione europea. Available online: www.europarl.europa.eu/factsheets/it (accessed on 1 June 2019).

Resende, A. 2019. Análise da evolução dos modelos de gestão de recursos hídricos no Brasil. Available online: https://www.ecodebate.com.br/2019/05/22/analise-da-evolucao-dos-modelos-de-gestao-de-recursoshidricos-no-brasil-artigo-de-alexsandra-resende/ (accessed on 3 June 2019).

Rogers, Peter, and Alan Hall. 2003. Governança e Política Nacional de Recursos Hídricos: Qual a posição da Gestão das Águas no Brasil? Paper presented at IV Encontro Nacional da ANPPAS, Brasília, Brasil, 4-6 June 2008; Edited by Samira Isabeck de Oliveira, Hildelano Delanusse Theodoro and Pedro Roberto Jacobi.

Santilli, Juliana. 2007. Aspectos jurídicos da Política Nacional de Recursos Hídricos. Série Grandes Eventos-Meio Ambiente. Available online: http://www.estig.ipbeja.pt/ \{\}ac_direito/Santilli.pdf (accessed on 6 June 2018).

Souza Júnior, Cleécio Barbosa, Marianna Siegmund-Schultze, Johann Köppel, and Maria do Carmo Sobral. 2017. Sinais de um problema crônico: A governança hídrica carece promover os comitês de bacias, coordenar planos e gerir informações. SP v. 12, n. 6. Taubaté: Revista Ambiente e Água. [CrossRef]

Vidale, Enrico, Davide Pettenella, Laura Secco, and Paola Gatto. 2012. Pagamenti per i servizi ambientali. Teoria sistema Giuridico e implementazione. Arezzo: Rivista Sherwood—editore Compagnia delle foreste s.r.l.

(C) 2019 by the authors. Licensee MDPI, Basel, Switzerland. This article is an open access article distributed under the terms and conditions of the Creative Commons Attribution (CC BY) license (http://creativecommons.org/licenses/by/4.0/). 